\title{
THE ENGLISH PRONUNCIATION TEACHING IN EUROPE SURVEY: SELECTED RESULTS
}

\author{
${ }^{1}$ ALICE HENDERSON ${ }^{1}$ \\ DAN FROST ${ }^{I}$ \\ ELINA TERGUJEFF ${ }^{2}$ \\ ALEXANDER KAUTZSCH ${ }^{3}$ \\ DEIRDRE MURPHY ${ }^{4}$ \\ ANASTAZIJA KIRKOVA-NASKOVA ${ }^{5}$ \\ EWA WANIEK-KLIMCZAK ${ }^{6}$ \\ DAVID LEVEY ${ }^{7}$ \\ UNA CUNNINGHAM \\ LESLEY CURNICK ${ }^{9}$ \\ Université de Savoie ${ }^{1}$ \\ University of Jyväskylä ${ }^{2}$ \\ University of Regensburg ${ }^{3}$ \\ Trinity College Dublin ${ }^{4}$ \\ University of Skopje ${ }^{5}$ \\ University of Łódź \\ University of Cádiz ${ }^{7}$ \\ Stockholm University ${ }^{8}$ \\ Université de Lausanne ${ }^{9}$
}

\begin{abstract}
This paper provides an overview of the main findings from a European-wide on-line survey of English pronunciation teaching practices. Both quantitative and qualitative data from seven countries (Finland, France, Germany, Macedonia, Poland, Spain and Switzerland) are presented, focusing on teachers' comments about:

- their own pronunciation,

- their training,

- their learners' goals, skills, motivation and aspirations,

- their preferences for certain varieties (and their perception of their students' preferences).

The results of EPTiES reveal interesting phenomena across Europe, despite shortcomings in terms of construction and distribution. For example, most respondents are non-native speakers of English and the majority of them rate their own mastery of English pronunciation favourably. However, most feel they had little or no training in how to teach pronunciation, which begs the question of how teachers are coping with this key
\end{abstract}

\footnotetext{
${ }^{1}$ Henderson and Frost are listed first because they did the final editing. Thereafter, authors are listed in alphabetical order of the country whose data they gathered and analysed. The order of the other authors thus reflects neither hierarchy nor significance of individual contributions, as this is a truly collaborative project and article.
} 
aspect of language teaching. In relation to target models, RP remains the variety of English which teachers claim to use, whilst recognizing that General American might be preferred by some students. Differences between countries are explored, especially via replies to open-ended questions, allowing a more nuanced picture to emerge for each country. Other survey research is also referred to, in order to contextualise the analyses and implications for teaching English and for training English teachers.

\section{Introduction}

English pronunciation teaching has been the subject of several surveys but mainly in English-speaking countries, such as Canada (Foote, Holtby \& Derwing, 2011; Breitkreuz, Derwing and Rossiter, 2002), Australia (Macdonald, 2002), and Great Britain (Bradford and Kenworthy, 1991; Burgess and Spencer, 2000). The attitudes towards pronunciation and the teaching practices of EFL teachers in Ireland were examined by D. Murphy (2011). Walker's survey of teachers in Spain (1999), which included some questions about training to teach pronunciation, is a relatively rare example of a study focusing on the issue in another European country. Relevant studies have been carried out recently in Poland, Serbia and Finland but have tended to focus on the learner's perspective.

English pronunciation researchers in Poland have concentrated on two major issues: firstly, the attitudes of the learners towards native speaker models (e.g. Kul, Janicka and Weckwerth 2005, Waniek-Klimczak and Klimczak 2005) and secondly, the degree of success in reaching the models in the learning process (e.g. Gonet, Szpyra-Kozłowska and Święciński 2010, Nowacka 2010). Although the studies adopt a learner rather than a teacher perspective, their results may be relevant for both, as the majority of participants are university students training to become teachers of English. Thus, the fact that university students recognise the relevance of native speaker models (with a strong preference for RP), but do not necessarily believe they will be able to reach the goal of native-like accent (see different views in Kul et al. 2005) may affect their attitudes towards the specification of goals in pronunciation teaching.

Paunivic (2009) presented a similar perspective in the Serbian context. She showed that complex interactions of sociolinguistic constructs were influential in shaping trainees' attitudes and their notion of the EFL teacher. The division between "foreign and incorrect" and "standard and correct" surfaced as most distinctive in the participants' responses, which favoured the latter, especially the British and American varieties, participants dismissing even native speakers as "foreign" if they sounded markedly regional.

In Finland, English pronunciation teaching has not been a frequently researched topic. Some insights into teaching materials and practices in the classroom are offered by Tergujeff (2010a, in print) and by two recent works: Lintunen (2004) and Tergujeff et al. (2011). Both studies include a survey section concentrating on phonetic teaching methods in English pronunciation teaching, but as opposed to the present study, the Finnish surveys were aimed at learners, not teachers.

Therefore, to the best of our knowledge, no study has extensively explored and compared how English pronunciation is taught in several European countries. The English Pronunciation Teaching in Europe Survey (EPTiES) seeks to fill this gap. 
Teachers from ten European countries created and administered the survey: Finland, France, Germany, Ireland, Macedonia, The Netherlands, Poland, Spain, Sweden and Switzerland. The current article explores the survey's results for seven of these countries, focusing on the following issues: teacher training; teachers' views of their own pronunciation; teachers' awareness of their students' goals and skills; teachers' awareness of students' motivation to speak English and of their aspiration to achieve native-like pronunciation.

\section{Survey Design \& Administration}

The survey, designed and administered using the open-source application LimeSurvey, has 57 questions, requesting for example: participant information; teachers' views on the pronunciation-related training they received; information about which varieties and norms are used in the classroom (for receptive \& productive work). Certain questions, such as "Please list your teaching qualifications", are formulated to reflect specific national contexts. Likert scale items are used, as well as several yes - no questions which are followed by a request for more information. The questions about teacher training are open questions, whereas others permit several answers to be chosen from a list, such as the questions about models and norms ${ }^{2}$.

The survey was open from February 2010 until September 2011 and a total of 843 people replied, with 481 completed surveys. Attempts were made to contact teachers at all levels of the private and public sectors by several means, including personal contacts and mailing lists of professional bodies such as teachers' associations (e.g. SUKOL in Finland, TESOL-France, ELTAM in Macedonia, ETAS in Switzerland). Educational institutions and administrative structures were also contacted directly (Finland, France and Germany). Invitations were distributed internationally via the Linguist List and "promotional" bookmarks were handed out at various conferences over a two-year period.

The results presented include only countries for which there were at least 12 completed surveys (Table 1), which unfortunately excludes Ireland (8), the Netherlands (0) and Sweden (1). As may be expected, some questionnaires are incomplete, often with only a few items left unanswered; therefore, the number of respondents for a given question is indicated in tables only when it differs from those in Table 1 below.

\begin{tabular}{|c|c|c|}
\hline Category & $\mathbf{N}^{\circ}$ of respondents per country & $\mathbf{N}^{\circ}$ of records completed \\
\hline Finland & 103 & 76 \\
\hline France & 65 & 52 \\
\hline Germany & 362 & 270 \\
\hline
\end{tabular}

\footnotetext{
${ }^{2}$ The latter is a potential weakness of the survey design, as will be shown in the discussion of models/varieties.
} 
Alice Henderson, Dan Frost et alii

\begin{tabular}{|c|c|c|}
\hline Category & $\mathbf{N}^{\circ}$ of respondents per country & $\mathbf{N}^{\circ}$ of records completed \\
\hline Macedonia & 36 & 13 \\
\hline Poland & 20 & 12 \\
\hline Spain & 31 & 20 \\
\hline Switzerland & 18 & 16 \\
\hline Total & $\mathbf{6 3 5}$ & $\mathbf{4 5 9}$ \\
\hline
\end{tabular}

Table 1. Participants per country, total $n^{\circ}$ of respondents $/ \mathrm{n}^{\circ}$ of completed surveys

\section{Findings: Teachers}

This section is divided into two parts. The first provides background information about the respondents in relation to: gender; average age and average number of years teaching; level and type of education; native language; teaching context (public/private, age of learners). The differences among countries will be referred to in the further analyses where they have an important impact (e.g. on the results related to attitudes and norms). The second section looks at teachers' views on the relative importance of English and of pronunciation, as well as teachers' self-assessment of their pronunciation.

Respondents were predominantly female $(77 \%)$ for 6 of the 7 countries but there are some important differences: $95.1 \%$ in Finland, $92.3 \%$ in Macedonia, $83 \%$ in Switzerland, $75 \%$ in France \& Poland, and $72.45 \%$ in Germany. It is interested to note that in Spain, $65 \%$ of those who completed the questionnaire were male. This was somewhat surprising given that language teaching in Spain, particularly at primary and secondary school level, has tended to be female dominated. Although it is true that more men are entering the profession, these figures may not be significant - of the 31 teachers who initially responded to the questionnaire but did not necessarily complete it, 16 were male and 15 were female.

The overall average age is 42.95 years, with averages from Poland and Macedonia well below this. The average age and years of experience is lowest for the Polish respondents: $17 / 20$ were aged 22-26, with 2-3 years of teaching practice. This is significantly lower than the overall survey average of 16.13 years' teaching experience. Respondents in Macedonia show a slightly higher range of age and experience: average age 29 (from 28-50 years) and 8 years' teaching experience (from 3-34 years). The average age in Finland is 44.6 years (24-67 years) with an average of 16 years' teaching experience, with a range of 0 to 44 years. German figures are almost exactly the same in both average and range: average age 44.68 (ranging from 24 to 66) and 15.99 years average experience (1-41 years). Even though France and Switzerland have the same average age (46), the former averaged 21 years' teaching experience as against 15 years in Switzerland. This seems to suggest that in France, respondents are mainly career teachers from the outset, whereas in Switzerland, English teaching is probably not the 
participants' first career. Finally, almost half (45\%) of Spanish respondents are over the age of 45 with more than 15 years' experience. However, this can largely be explained by the fact that most work in attractive large or medium-size towns and cities. Jobs in popular urban centres tend to be taken by candidates with the most years of service.

In terms of level of education, respondents in only two countries tend to hold specific EFL qualifications: in Switzerland 13/17 described themselves as TEFL-trained ${ }^{3}$ with two having $\mathrm{PhDs}^{4}$. The majority (94.2\%) of Finnish respondents have finished at least an MA degree; in Finland, qualified EFL subject teachers hold an MA degree in English with a teacher training programme/pedagogy as a minor subject in the degree. The young Polish respondents are recent graduates or are still in the process of doing MA courses. All Macedonian respondents hold BA degrees, one an MA degree, and one a CPE certificate. In the case of Spain, all except one of the teachers had a University degree and $25 \%$ had an MA or PhD. In France, over half of the respondents have passed the CAPES or the Agrégation (the French national competitive exams for recruiting teachers) and many other different levels and types of qualifications were listed ${ }^{5}$.

Concerning native language, despite the fact that overall $88.21 \%$ of respondents describe themselves as non-native speakers of English, there are important differences among the different countries. In Switzerland they were predominantly native English speakers $(83 \%)$, but in neighbouring France, three-quarters of respondents were nonnative speakers. Most participants in Finland were non-native speakers of English (99.0\%), as was the case in Germany (95.87\%) and Spain (74.19\%). In Macedonia and Poland all respondents were non-native English speakers.

Respondents teach predominantly in the public sector $(92.2 \%$ in Finland, $93.93 \%$ in Germany, $80.65 \%$ in Spain), except for Macedonia, where $76.92 \%$ of respondents teach in the private sector. Polish respondents teach in the public sector, with additional classes taught in private language schools in the evenings or at weekends. Swiss respondents teach mainly adults in both private $(61 \%)$ and public $(39 \%)$ sectors. French respondents also teach primarily adults, working in tertiary education (76.9\%) and high schools $(21.5 \%)$. In contrast, Finns are quite evenly distributed across different teaching contexts: i.e. primary $(29.1 \%)$, lower secondary (31.1\%), and upper secondary $(27.2 \%)$ level; only a few respondents teach in other contexts (vocational school, university, other). Three-quarters of participants in Germany teach 10-18 year olds: (40.50\%) at Gymnasium (age 10-18), followed by Realschule (age 10 to 16, 20.94\%), and Grundschule (age 6-10, 16.25\%). A slightly smaller proportion (13.50\%) teaches younger pupils (age 10-15) at Hauptschule.

Two items required participants to estimate the relative importance of English and of pronunciation in relation to other language skills; the averages were relatively high (4.66 and 3.77 respectively, with 5 being "extremely important"). In a third item, teachers selfevaluated their pronunciation (4.17, with 5 being native). This section discusses those results and begins to address the issue of the status of English.

Reassuringly, the overall figures for the importance of English are quite high in all countries, as one would anticipate from English teachers. In Finland, the average rating

\footnotetext{
${ }^{3}$ For example, having a DipTEFL, CELTA, MEd in TESOL.

${ }^{4}$ One in Entomology and the other in English Linguistics.

${ }^{5}$ One cannot take these exams without having completed an undergraduate degree and since 2011, a 2-year Master's programme must be completed before being allowed to teach.
} 
for the importance of English in relation to other languages was very high: 4.65. In their comments, the respondents frequently mentioned the status of English as a global language, and also issues related to the respondents' own language use, e.g. "I teach English, I read in English, I communicate in English with friends abroad". However, one respondent pointed out that "English is not the only foreign language people should learn". This comment relates to recent debates around language policy and education in Finland, where foreign language skills are highly valued and vast resources are invested in language education. In recent years however, pupils have been choosing to study fewer optional languages than before (see for example Kangasvieri et al. 2011, Sajavaara et al. 2007). The concern is that Finns' language skills may diminish as fewer pupils study German, French and Russian, whereas nearly all study English. The global status of English is surely one reason behind the new tendency of language choices at school, and pupils and parents may think that knowing English, in addition to the official languages Finnish and Swedish, is enough. Moreover, according to a recent survey, English is widely present in the everyday life of younger Finns in particular.

The results from Macedonia point to a similar situation. Respondents from Macedonia allotted high values to the importance of English in relation to other languages (4.69/5 on average). In the open comments for that item, respondents mentioned the economic relevance of English and the communicative relevance of English as a world language. The responses given for item $n^{\circ} 61$, which explored the importance of English pronunciation in relation to other language skills, echo these notions. Although 19.2\% rated the importance of pronunciation as 5 (extremely important), in effect signifying that pronunciation is seen as equally important as other language skills, most of the respondents opted for the lower ratings $(52.6 \%$ and $26.9 \%$ for $4 / 5$ and $3 / 5$ respectively). In their comments, communication clearly takes priority over correct pronunciation: English "needs to be learnt" because it is "the language of global trade" and "all information is in English". Teachers - much to their credit - seem to be aware that communication is the goal of learning English for their learners. Pronunciation as a skill then is viewed through the lenses of this aim and is pushed down on the priority list, i.e. English is solely learnt for communicative purposes.

At the opposite end of the spectrum, in Spain practically all informants gave great importance to pronunciation in relation to other language skills (item $n^{\circ} 61$ ). That necessity to improve English pronunciation skills is widely accepted and the urgent need for specific teacher training in this area has been advocated for some time (see Donovan 2001; Levey 1999, 2001; Pavon, 2001; Pavon and Rosado, 2003). Analysis of Spanish data reveals that pronunciation remains a problem and informants recognize that insufficient time and resources are spent on it. The reasons most commonly cited for not dedicating more time to it centred on two aspects: first, the difficulty it constitutes for both students and teachers, and secondly, the fact that teachers felt their hands were tied by curricular demands and by the need for schools to obtain results:

"Spanish students need help with their pronunciation but in the end we have to be realistic... unfortunately the truth is that students must pass a written exam at the end of the year - there is no oral test. So I'm sorry to say oral skills are not the priority". 
The results from Germany raise the question of the nativization of English in Europe, as well as the possible categorization of English as an "additional" instead of a foreign language (Hilgendorf, 2007:144). The fact that German respondents rate the overall importance of English as high (4.67) does not come as a surprise. It nicely mirrors the status English has gained in primary and secondary education in the last decades resulting from trends in European and national educational policy-a development which is systematically documented by the German government's federal office for statistical analysis (Statitisches Bundesamt 2003a, 2011a, 2011b).. In schools of general education (Grundschule, Hauptschule, Realschule, Gesamtschule, Gymnasium) the percentage of pupils learning English has increased from $69.1 \%$ in the school year 2002/2003 to $86.7 \%$ in the school year 2010/2011 (Statistisches Bundesamt 2003a, 2011a). A similar increase can be witnessed in vocational schools from $42.1 \%$ to $51.7 \%$, respectively (Statistisches Bundesamt 2003b, 2011b). The development in schools of general education goes hand in hand with the introduction of English as a compulsory subject in primary schools in many of the 16 federal states of Germany, who are independent from the federal government in establishing and implementing educational policies. The increase in the number of English learners in the vocational sector seems to be a consequence of the requirements of a globalized workplace. Hilgendorf's (2007:144) suggestion of "a shift in the status of the language from that of a foreign language to that of an additional language" obviously holds for other European countries, as well. But if and to what extent Germany and other European countries find themselves in a process of "ongoing nativization and acculturation of English" (Hilgendorf 2007: 145) remains to be seen once this new generation of pupils (who have started learning English at an earlier age) grows up.

\begin{tabular}{|c|c|}
\hline \multicolumn{2}{|c|}{ Importance of English } \\
\hline Finland (n=78) & 4.65 \\
\hline France $(\mathrm{n}=52)$ & 4.48 \\
\hline Germany (n=270) & 4.67 \\
\hline Macedonia (n=14) & 4.57 \\
\hline Poland (n=14) & 4.92 \\
\hline Spain (n=23) & 4.75 \\
\hline Switzerland (n=16) & 4.63 \\
\hline Average & 4.66 \\
\hline
\end{tabular}

Table 2. Average results from item $\mathrm{n}^{\circ} 60$ : For you personally, how important is English in relation to other languages? Please rate from 1 to 5 , with 1 as "not important at all" and 5 "extremely important". 


\begin{tabular}{|c|c|}
\hline \multicolumn{2}{|c|}{ Importance of pronunciation } \\
\hline Finland $(\mathrm{n}=78)$ & 3.90 \\
\hline France $(\mathrm{n}=52)$ & 4.02 \\
\hline Germany $(\mathrm{n}=270)$ & 3.72 \\
\hline Macedonia (n=14) & 3.14 \\
\hline Poland (n=14) & 3.92 \\
\hline Spain (n=23) & 4.2 \\
\hline Switzerland (n=16) & 3.5 \\
\hline Average & 3.77 \\
\hline
\end{tabular}

Table 3. Average results from item $n^{\circ} 61$ : For you personally, how important is pronunciation in relation to other language skills? Please rate from 1 to 5 , where $1=$ "the least important" and $5=$ "the most important".

Overall, teachers self-evaluated their pronunciation as being quite good (4.17 on a scale from 1-5, with 5 being excellent). However, the question was perhaps misinterpreted: 'Your own pronunciation skills' could conceivably refer to one's knowledge of phonology/phonetics or one's ability to pronounce English. The fact that German respondents rate their own pronunciation skills worse (3.99) than teachers from other European countries (except Poland at 3.92) is matched in the open answers by a high level of awareness that they are not perfect. The following contribution serves as a case in point: "I am able to avoid the specific German accent, so native speakers often can't tell where I'm from, but they certainly can tell that I am not a native speaker of English". The Poles' low average probably reflects a relatively critical self-evaluation with respect to their own accent. The respondents are young and lacking in experience, and more importantly they have just graduated from institutions which devote considerable time and effort to making students aware of how much work they still have ahead of them.

\begin{tabular}{|c|c|}
\hline \multicolumn{2}{|c|}{ Teachers' level of pronunciation, self-assessed } \\
\hline Finland $(\mathrm{n}=78)$ & 4.23 \\
\hline France $(\mathrm{n}=52)$ & 4.33 \\
\hline Germany $(\mathrm{n}=268)$ & 3.99 \\
\hline Macedonia $(\mathrm{n}=14)$ & 4.43 \\
\hline
\end{tabular}




\begin{tabular}{|c|c|}
\hline \multicolumn{2}{|c|}{ Teachers' level of pronunciation, self-assessed } \\
\hline Poland (n=14) & 3.92 \\
\hline Spain $(\mathrm{n}=22)$ & 4.25 \\
\hline Switzerland $(\mathrm{n}=16)$ & 4.1 \\
\hline Average & 4.17 \\
\hline
\end{tabular}

Table 4. Average results from item $\mathrm{n}^{\circ}$ 63: How would you rate your own pronunciation skills? Please rate from 1 to 5 , where 1 = "extremely poor" and 5 = "excellent".

\section{Findings: Teacher training}

The three questions concerning teacher training were:

- In relation to pronunciation, please rate the teacher training you received from 1 to 5, with 1 as "extremely poor" and 5 as "excellent".

- Please tell us how much training you received specific to teaching pronunciation. Feel free to mention any period of time (hours, months, years, etc.).

- Please explain the content and/or style of the training you received. Feel free to mention types of courses, approaches, etc.

Participants' comments reveal that many if not most appear to be amateurs when it comes to teaching pronunciation. By amateurs, we mean not only that the participants clearly love their subject (from the Latin, amator), but also that they appear to have received little or no professional training which deals specifically with how to teach pronunciation. It is surprising that whereas the average self-assessment of pronunciation skills was quite high (4.64), the average rating of their training in relation to teaching pronunciation should be so much lower (2.91, where $1=$ extremely poor). Moreover, the average might have been even lower, as participants may have confused "phonetics" and "pronunciation", despite the clear formulation of the questions.

When asked about the quality of pronunciation training they had received, only in Finland was the average score above 3 (3.16 on a Likert scale from 1-5, where 5 was "excellent"). One of the most frequent follow-up comments (given by nearly half of the Finnish participants) referred to one or more pronunciation courses or described an equivalent time spent on pronunciation training. Some respondents clearly pointed out that they had been taught pronunciation but not how to teach it. Respondents seldom learnt the skill of pronunciation teaching outside their teacher training (e.g. by studying phonetics separately), nor was pronunciation teaching intertwined with other topics.

In Switzerland the replies about quantity of training varied dramatically, from "none at all" (3 respondents), to vague references to training during CELTA courses, to a more specific description of a 16-week course during a Bachelor's programme. The latter did not address the teaching of phonetics, but only "learning the symbols". Considering the average age of the teachers and the number of years they have been in service, perhaps it 
is not surprising they could not give more precise details about how much pre-service training they had received. Nevertheless, when asked to explain the content or style of the training received, there were some more specific comments such as: "watched teachers on DVDs", "A speaker comes and then in groups we practice their teaching methods." Some people claimed to be self-taught: "Mainly gleaned from workshops and using course books." and another "... CELTA required a written paper on teaching it. The rest has been basically self-taught." There were also references to specific universities, books, biographies, and authors.

German English teachers also feel that their training was not particularly satisfactory with respect to pronunciation teaching (2.86). They provided a plethora of revealing comments which raise several issues. First, some misunderstood the question in terms of what counts as teacher training and mainly referred to university classes:

- "one semester of Language Lab exercises, a transcription class (one semester), a lecture on English Pronunciation (one semester) - but I learned most during 10 months as an exchange student in Scotland (by 'doing')"

- "I studied at times of the former GDR that is why I didn't get much training and can't express it in hours, etc. But I had an excellent phonetics teacher"

- "Phonetics classes at university consisting of transcription and theory (stress, pitch etc.) and practical training to improve our own pronunciation"

There is also a widespread opinion that having good pronunciation is sufficient for teaching pronunciation, however it may be acquired:

- "I went to study abroad, one year in Australia. Best pronunciation training ever"

- "None at all, but I lived in GB for a year"

- "Professors at the university and teacher trainers presumed that if one is able to pronounce correctly, they will somehow be able to make the children pronounce correctly, too"

Obviously, neither spending time in an English-speaking country nor having good pronunciation oneself guarantee that one can teach pronunciation effectively. And while there may be a lack of quality trainers in certain contexts ("Very little time was devoted to teaching pronunciation, probably because one of the trainers spoke English with a very heavy German accent"), in some cases respondents did report on practical techniques they acquired during teacher training. In this, they were similar to many respondents in Switzerland:

- "during teacher training: working in a language lab, listen and repeat exercises (individual or in groups) with teacher or CD, ways of introducing new words and their pronunciation, ways of controlling the correct pronunciation"

- 'instructions on how to teach pronunciation to children in our 'Seminar' (teacher training group)"

In their comments, 19 of the French respondents said they had very little or no training, 19 mentioned only the phonetics classes they received as undergraduates themselves and 9 mentioned training they had received at conferences, etc. which they had attended since becoming teachers. It is possible that there was some confusion between "phonetics" and "pronunciation", as well as between the education received by respondents as undergraduates and in their actual teacher training. However, a more likely explanation is that the paucity of teacher training in pronunciation is so great that for many respondents, the only experience on which they could draw was often their first 
year phonetics and phonology lectures. In fact, very few respondents in France had anything positive to say about their teacher training regarding the teaching of pronunciation: "We had a few classes about the pronunciation of English, intonation etc. but just the theory and no actual demonstration of how to teach them". However, as one aptly concluded: "knowing about something is certainly not the same as knowing how to teach it".

In Poland, few respondents (18.75\%) said they had received formal training in teaching pronunciation. In Spain, training was largely limited to one-year university courses, and in one case two years. The quality, content and the practical application of these courses in phonetics varied from university to university. Only 3 respondents had received further training or taken subsequent courses after university, $27.77 \%$ of the informants had received no or practically no formal training and a further $22.22 \%$ described themselves as self-taught.

Macedonian teachers gave low ratings with regard to their training to teach pronunciation, yet in their comments they highlighted the necessity of receiving good training: "I believe the teacher should be very well trained in order to be good at teaching pronunciation". They reported that their first (and sometimes only) explicit instruction in pronunciation was during their undergraduate course in English Phonetics and Phonology: theoretical lectures on segmentals and prosody as well as various types of activities for practicing phonetic symbols and phonemic transcription, English sound formation and categorization, basic phonetic and phonological rules as well as different types of intonation patterns. In several responses teachers referred to being self-taught; additional training which they mentioned was related to English teaching in general and not specifically pronunciation.

Similarly, when respondents from Finland were asked to describe the content and/or style of their training, they listed very traditional pronunciation teaching methods: phonetics and transcription, repetition and drills, discussion exercises, reading aloud, and listening tasks. Training in the language lab was mentioned frequently, and some mentioned a theoretical orientation, or that training had mainly consisted of lectures.

To conclude, limited or no specific training in teaching pronunciation seems to be the norm, but non-native English speaker respondents have usually received training in improving their own pronunciation.

\section{Findings: Learners}

This section covers teachers' perceptions of their students, and more specifically of their goals, skills, motivations and aspirations. The questions were as follows:

- Rate your awareness of your learners' goals. Please rate from 1 to 5, with 1 as "no awareness" and 5 as "excellent awareness".

- Please rate your awareness of your learners' skills. Please rate from 1 to 5 , with 1 as "no awareness" and 5 as "excellent awareness".

- Please rate from 1 to 5 how motivated you feel your learners are to speak English, with 1 as "totally unmotivated" and 5 as "extremely motivated". 
- To what extent do you feel your students aspire to have native or near native pronunciation of English? Please rate from 1 to 5, with 1 as "do not aspire to this at all" and 5 as "aspire to this $100 \%$ ".

Interpretation of the results requires caution. For example, German English teachers have the second lowest awareness of their students' goals (3.36) after France and the lowest awareness of their students' skills (3.61). An interpretation along the lines of reduced interest in the students or a reserved teacher-learner relationship would be an overgeneralization that requires a more representative basis for comparison from the other countries, as well as additional survey data, preferably learner-centred.

It would seem from the results that teachers in France are marginally more aware of their students' skills (3.98 on a scale from 1 to 5) than of their goals (3.77/5). If this is the case, then the reasons are quite possibly cultural. The French academic grading system is based on subtracting marks for errors from a total of 20 marks. In this way, teachers are encouraged to search for weaknesses in their students, rather than for strengths. As for the relative lack of awareness of learners' goals, this may be due to their irrelevance in France's "top-down" society. France operates a national curriculum in secondary schools and also in some tertiary institutions, so teachers are generally not expected to take the needs of the learners into account themselves. Moreover, a certain distance is maintained between teachers and their students, with the vous form and Monsieur or Madame being used to address teachers at both secondary and tertiary levels. Lastly, large class sizes do not help to encourage meaningful interaction between students and their teachers; in universities modern language class sizes may run to 50 or more. It would thus seem logical that teachers in France are less aware of their learners' goals than in other countries - in fact we had expected the average to be even lower.

In Finland the difference between awareness of goals (3.58) and of skills (3.91) was even more marked, but teachers' further comments help to explain this, as well as the fact that many of the Finnish respondents were teaching at primary level $(29.1 \%)$ or lower secondary $(31.1 \%)$ in contrast to France, where the learners tend to be adults. Some Finnish respondents referred to their own goals for the learners, e.g. "I know what their goals should be," but others mentioned learners having varied goals. Some teachers working in the primary level seem to be of the opinion that young learners do not have goals. When asked to comment on their awareness of learners' skills, the most frequently mentioned aspect by the Finnish respondents was lack of time or big groups. However, respondents also stated it is the teacher's duty to be aware of the learners' skills and development.

The teachers in Switzerland showed a relatively high awareness of learners' goals (4) and claim to have a slightly lower awareness of learners' skills (3.75). However, they felt that their students were highly motivated to speak English (4.25). This was the highest response to this question and this may reflect the perceived importance of speaking English in Switzerland today (see Dürmüller (2002), especially in higher education. 


\begin{tabular}{|c|c|}
\hline \multicolumn{2}{|c|}{ Teachers' awareness of Learners' goals } \\
\hline Finland (n=78) & 3.58 \\
\hline France (n=52) & 3.77 \\
\hline Germany (n=269) & 3.36 \\
\hline Macedonia & 4 \\
\hline Poland (n=14) & 3.57 \\
\hline Spain (n=22) & 3.7 \\
\hline Switzerland (n=16) & 4 \\
\hline Average & 3.71 \\
\hline
\end{tabular}

Table 5. Average results from item $n^{\circ} 64$ : Rate your awareness of your learners' goals. Please rate from 1 to 5 , where 1 = "no awareness" and 5 = "excellent awareness".

\begin{tabular}{|c|c|}
\hline \multicolumn{2}{|c|}{ Teachers' awareness of Learners' skills } \\
\hline Finland (n=78) & 3.91 \\
\hline France (n=52) & 3.98 \\
\hline Germany (n=269) & 3.61 \\
\hline Macedonia (n=14) & 4.57 \\
\hline Poland (n=14) & 4 \\
\hline Spain (n=21) & 3.95 \\
\hline Switzerland (n=16) & 3.75 \\
\hline Average & 3.96 \\
\hline
\end{tabular}

Table 6. Average results from item $\mathrm{n}^{\circ}$ 65: Please rate your awareness of your learners' skills.

Please rate from 1 to 5 , where $1=$ "no awareness" and 5 = "excellent awareness".

The two questions on learners' general motivation to learn English and their aspiration to achieve native-like pronunciation show that, overall, the former is greater than the latter, in teachers' estimations. In Poland, the low aspiration to sound native (2.71) is 
understandable as most of the respondents teach children. German teachers' estimations of the students' motivation to speak English (3.53) is the third lowest after Poland and France, while their evaluation of the students' aspiration to sound native-like (2.94) is average.

Even though the Finnish respondents estimate their learners' motivation to be quite high (3.88 on average), the comments reveal very clearly that the learners have varied levels of motivation; some are highly motivated whereas some show little interest. In terms of aspirations, as indicated by teachers' comments, learners in Finland opt for intelligible communication in the target language rather than native-like pronunciation, and here it seems that famous Finns such as motor sport heroes have shown them the example: "Formula One drivers have proved to Finnish students it's not necessary to pronounce English perfectly to become rich and famous".

It is not hard to interpret the results for Switzerland, with the highest average for motivation to learn English (4.25) but a lower aspiration to sound native (3.38). It is a country with four national languages, with many Swiss using English to communicate with compatriots who speak a different language from themselves. Several Masters courses are taught in English and many see English as essential for good job prospects, but none of these reasons require native or near native pronunciation of English.

It would appear from the results that French learners are among the least motivated to learn English. Respondents believe that their learners' aspiration to achieve native or near native pronunciation is relatively low $(2.9 / 5)^{6}$. An explanation may lie in institutional, linguistic and cultural factors. Firstly, many of the French respondents teach partly or exclusively EAP \&/or ESP, as learning a foreign language is a national requirement in all disciplines at tertiary level in France; motivation and aspirations are therefore often lower in language classes (Taillefer 2002). Secondly, it must be pointed out that French and English are so very different phonologically (Hirst \& Di Cristo 1998; Blum 1999; Vaissière; 2002; Frost 2010), that even the least pragmatic French learners of English know that native-like fluency is a very difficult goal. Thirdly, the French traditionally attribute a relatively high importance to written texts, both when learning their native language and foreign languages (Duchet 1991). This often translates in difficulties acquiring the phonological system of a foreign language later on. And finally, the French tend to equate "fluent" with "perfect"; therefore even communicative competence is a sort of perfection that they might not dare to aspire to. In this way, they may resemble the Spanish respondents, who had the lowest average (2.6) for aspiration to sound native-like.

\footnotetext{
${ }^{6}$ This would tally with the results to items $60 \& 66$ on the importance of English in relation to other languages and motivation to speak English respectively, where French averages (though above the median on the 1-5 Likert scale) were the lowest (4.48) and second lowest (3.4) of the seven countries.
} 


\begin{tabular}{|c|c|}
\hline \multicolumn{2}{|c|}{ Students' motivation to study English } \\
\hline Finland $(\mathrm{n}=78)$ & 3.88 \\
\hline France $(\mathrm{n}=52)$ & 3.4 \\
\hline Germany $(\mathrm{n}=269)$ & 3.53 \\
\hline Macedonia (n=14) & 3.93 \\
\hline Poland (n=14) & 3.35 \\
\hline Spain (n=21) & 3.65 \\
\hline Switzerland (n=16) & 4.25 \\
\hline Average & 3.71 \\
\hline
\end{tabular}

Table 7. Average results from item $n^{\circ} 66$ : Please rate from 1 to 5 how motivated you feel your learners are to speak English, where 1 = "totally unmotivated" and 5 = "extremely motivated".

\begin{tabular}{|c|c|}
\hline \multicolumn{2}{|c|}{ Students' aspiration to achieve native level } \\
\hline Finland $(\mathrm{n}=78)$ & 3.17 \\
\hline France $(\mathrm{n}=52)$ & 2.9 \\
\hline Germany $(\mathrm{n}=269)$ & 2.94 \\
\hline Macedonia $(\mathrm{n}=14)$ & 3.43 \\
\hline Poland $(\mathrm{n}=14)$ & 2.71 \\
\hline Spain $(\mathrm{n}=21)$ & 2.6 \\
\hline Switzerland (n=16) & 3.38 \\
\hline Average & 3.02 \\
\hline
\end{tabular}

Table 8. Average results from item $\mathrm{n}^{\circ} 67$ : To what extent do you feel your students aspire to have native or near native pronunciation of English? Please rate from 1 to 5, where 1 = "do not aspire to this at all" and $5=$ "aspire to this $100 \% "$ ". 


\section{Findings: Models of English}

At the end of the survey, four items covered models of English:

- For RECEPTIVE work (listening, reading), which variety(ies) or model(s) of English do you use in your classes? You may choose more than one answer.

- “...”... do your learners generally prefer?

- For PRODUCTIVE work (speaking, writing), which variety(ies) or model(s) of English do you use in your classes? You may choose more than one answer.

- “..." ... do your learners generally prefer?

This was not a ranking item and participants could give multiple answers. For example, $94.7 \%$ of respondents in Finland chose RP (Received Pronunciation) as the variety they prefer to use for receptive work but this did not exclude them from choosing other varieties, too. Only the data for the three most frequently selected reference accents for reception and for production work will be discussed: RP (Received Pronunciation, GA (General American) and IE ("a type of International English").

Throughout the countries, a clear discrepancy was found between which varieties/models teachers use and which they think their students generally prefer. Received Pronunciation (RP) is used by most teachers (receptive work RP: 91.63\%, GA: $70.73 \%$; productive work RP: $84.2 \%$, GA: $53.84 \%$ ). On the other hand, teachers indicate that General American (GA) is preferred by students, but the difference is less clear-cut (receptive work RP: 64.53\%, GA66.69\%; productive work RP: 55.24\%, GA: 63.35\%). A type of "international variety" is also frequently mentioned by respondents for both types of work, and as a variety they use and which their learners prefer.

Poland is the only country where $100 \%$ of teachers chose RP as the variety they use for receptive and productive work. Anecdotal evidence shows that, partly because teachers are aware that their learners are exposed to and enjoy GA through films and music, during class they use RP materials. At university level, only Poznan offers a choice of target variety, all the others use RP. Similarly, participants in Spain overwhelmingly chose RP, such that their results are the highest overall $(95 \%, 90 \%$ and $85 \%)$, except in the variety teachers chose for productive work $(75 \%)$, where only the French teachers chose RP less $(65.38 \%)$.

One of the teachers in Switzerland commented thus on RP: "I don't like the idea of propagating the Queen's English." This would seem to be a native speaker luxury, as a non-native teacher of English would probably never authorize themselves to say this. On the whole, non-native teachers seem to prefer a clear reference point when teaching English pronunciation and this is logically achieved by favouring one variety over the other. In particular, this simplifies the assessment process. In Macedonia, for instance, teachers favour using RP presumably because they were taught/trained in RP, the reference model they are familiar and comfortable with. However, in the survey it appears that they feel their students prefer General American. If pronunciation is stereotypically thought to be the skill that is least prone to modification, it would be interesting to explore teachers' willingness (and/or ability?) to adapt their pronunciation to the various demands of their learners (and not just in Macedonia). Another interesting observation in the Macedonian data was the preference of so-called "global English" where emphasis was placed on intelligibility as suggested in: "Global English means global/ non-native pronunciation, and yet intelligible communication". 
The German data reveals that $\mathrm{RP}^{7}$ is still the variety teachers choose, for both receptive $(91.19 \%)$ and productive work $(91.19 \%)$. General American however, is a respectable second, at least in reception $(80.08 \%)$; the same is true in France (RP: 80.77\%, GA: $78.85 \%$ ). In productive work, GA's status clearly lags behind RP (at $67.82 \%$ in Germany and 50\% in France), but by comparison with other European countries Germany ranks second after Macedonia (69.23\%), the lowest being Spain (35\%). Again, teachers in Macedonia may be making a nod toward their perceived students' preference for GA $(100 \%)$ in productive work.

In contrast to a clear preference for RP among teachers, the teachers' evaluation of the students' preferences seems less clear cut in both Germany and France. The survey suggests that RP and GA are almost equal alternatives for students in Germany, both in receptive (RP: $72.41 \%$, GA: $73.95 \%$ ) and in productive (RP: $72.03 \%$, GA: $68.97 \%$ ) work. The situation is arguably similar in France: reception (RP: $61.54 \%$, GA: $57.77 \%$ ) and production (RP: $51.92 \%$, GA: 44.23\%). In addition to other major varieties of English, the label "a type of international English" surprisingly ranks third with German respondents for students' preferences in production and reception, as well as for teachers' in production work. In terms of teachers' receptive work IE was only rated sixth (21.46\%), close to Scottish English $(24.90 \%)$ and Irish English $(22.61 \%)$ but far behind Australian English (37.93\%). This is quite likely to mirror the fact that audio samples of these varieties often accompany EFL textbooks.

In Finland, a substantial proportion of teachers also use other varieties/models, particularly for receptive work. For example using Australian English was nearly as popular as using "a type of international English" which came third most popular after RP and GA. Irish English, Scottish English and Canadian English were all mentioned by more than $20 \%$ of the Finnish respondents for receptive work. This is perhaps due to the fact that, as in Germany, EFL textbooks' audio CDs include different native and nonnative varieties (Tergujeff 2009, 2010b; Kopperoinen 2011).

In Switzerland, for receptive and productive work teachers favoured RP followed by GA. This corresponded to their perceived preferences for their learners, although one commented: "I believe learners need a pronunciation model of some description to promote intelligibility but I am not interested in forcing them to acquire a particular accent." The perceived preference for RP among learners was stronger in productive $(81.25 \%)$ than receptive $(68.75 \%)$. "A type of international" English was the third preferred option.

To conclude, based on the results for items 75 to 78 , it is clear that although RP is still the dominant form for both reception and production work in English, GA seems to be making inroads. The increased use of the Internet both in teaching and at home is perhaps an important factor here. From the teachers' point of view, it is easy enough to find audio and video examples of varieties to use in a formal class setting, but perhaps more important is on-line informal learning of English (Sockett, 2011). Web 2.0 technologies such as peer-to-peer file transfer and streaming have led to a previously unthinkable ease of access to media content, such as films and TV series which, given the American cultural hegemony in these domains, has led to European learners of English being exposed increasingly to American rather than British varieties of English.

\footnotetext{
${ }^{7}$ Many teachers possibly understand RP as being Southern British English, based on their comments.
} 
Therefore, in addition to textbook comparisons and classroom research, surely the influence of such informal influences merits more scrutiny. It is also not clear exactly what IE refers to but, as the third most frequent choice, deserves closer investigation.

\begin{tabular}{|c|c|c|c|c|c|c|}
\hline & \multicolumn{3}{|c|}{ Item n ${ }^{\circ}$} & \multicolumn{3}{c|}{ Item n ${ }^{\circ}$ 76 } \\
(\% of Ts, receptive work) & (\% of Ts, productive work) \\
\hline RP & GA & IE & RP & GA & IE \\
\hline Finland & 94.7 & 76.3 & 42.1 & 93.42 & 63.16 & 19.74 \\
\hline France & 80.77 & 78.85 & 44.23 & 65.38 & 50 & 26.92 \\
\hline Germany & 91.19 & 80.08 & 21.46 & 91.19 & 67.82 & 11.88 \\
\hline Macedonia & 92.31 & 46.15 & 23.08 & 76.92 & 69.23 & 46.15 \\
\hline Poland & 100 & 75 & 16.67 & 100 & 41.67 & 8.33 \\
\hline Spain & 95 & 70 & 30 & 75 & 35 & 10 \\
\hline Switzerland & 87.5 & 68.75 & 37.5 & 87.5 & 50 & 31.25 \\
\hline Average & $\mathbf{9 1 . 6 3}$ & $\mathbf{7 0 . 7 3}$ & $\mathbf{3 6 . 2 6}$ & $\mathbf{8 4 . 2}$ & $\mathbf{5 3 . 8 4}$ & $\mathbf{2 2 . 0 4}$ \\
\hline
\end{tabular}

Table 9: Results for items $n^{\circ} 75 \& n^{\circ} 76$ : Percentage of teachers who chose a variety for receptive $\&$ productive work

\begin{tabular}{|c|c|c|c|c|c|c|}
\hline & \multicolumn{3}{|c|}{$\begin{array}{c}\text { Item } \mathbf{n}^{\circ} 77 \\
(\% \text { of Ss, receptive work) }\end{array}$} & \multicolumn{3}{|c|}{$\begin{array}{c}\text { Item } \mathrm{n}^{\circ} 78 \\
(\% \text { of Ss, productive work) }\end{array}$} \\
\hline & $\mathbf{R P}$ & GA & IE & $\mathbf{R P}$ & GA & IE \\
\hline Finland & 65.8 & 86.8 & 15.8 & 65.8 & 79 & 19.7 \\
\hline France & 61.54 & 55.77 & 34.62 & $51.92 \%$ & 44.23 & 26.92 \\
\hline Germany & 72.41 & 73.95 & 14.94 & 72.03 & 68.97 & 12.64 \\
\hline Macedonia & 30.77 & 76.92 & 38.46 & 15.38 & 100 & 30.77 \\
\hline Poland & 66.67 & 66.67 & 16.77 & 66.67 & 50 & 16.77 \\
\hline Spain & 90 & 40 & 15 & 85 & 45 & 10 \\
\hline
\end{tabular}




\begin{tabular}{|c|c|c|c|c|c|c|}
\hline \multirow[b]{2}{*}{ Switzerland } & \multicolumn{3}{|c|}{$\begin{array}{c}\text { Item } \mathrm{n}^{\circ} 77 \\
(\% \text { of Ss, receptive work) }\end{array}$} & \multicolumn{3}{|c|}{$\begin{array}{c}\text { Item } \mathbf{n}^{\circ} 78 \\
(\% \text { of Ss, productive work) }\end{array}$} \\
\hline & 68.75 & 56.25 & 31.25 & 81.25 & 56.25 & 31.25 \\
\hline Average & 64.53 & 66.69 & 23.83 & 55.24 & 63.35 & 21.15 \\
\hline
\end{tabular}

Table 10: Results for items $n^{\circ} 77 \& n^{\circ} 78$ : Percentage of teachers who indicated their students' preference for a variety, for receptive \& productive work

\section{Conclusions}

The findings of this study have shed light on a cross-section of current themes in pronunciation teaching across Europe, as well as providing valuable aid for future studies. The three areas we have focussed on in this paper are teacher training, aims and objectives, and models/varieties.

Our findings suggest that teacher training in relation to the teaching of English pronunciation is woefully inadequate, according to the majority of participants. If this is true, Europe today is similar to the United States in the 1990s, where J.M. Murphy (1997) found that less than 50\% of MA TESOL programmes had modules devoted to phonology. This lack of training does not match the emphasis placed on English pronunciation in the Common European Framework of Reference (CEFR), where 'Phonological Control' is one of the descriptors in the Language Competence/Linguistic category. Pronunciation is also considered one of the key elements in the speaking component of major international English language proficiency tests such as IELTS, TOEFL and TOEIC. In other words, the apparent lack of teacher training in pronunciation is not representative of the requirements of English language learning, as many highly-regarded assessment procedures specifically refer to phonology.

Another crucial issue concerns the choice of objectives: should one aim for intelligibility and communicative competence and/or native-like pronunciation? The respondents' comments showed that the choice necessarily influences what teachers actually do with learners to achieve those objectives and how they learn to do that. In relation to such pedagogical dilemmas, the issue of informal learning must be addressed (Sockett, 2011): if games and online content provide constant, repetitive exposure to certain accents, what impact does this have on teachers' choices for classroom time?

In terms of varieties, RP is preferred by teachers though they do recognize that GA might be more popular amongst students (except in Switzerland). The term "International English", a popular choice across the seven countries, also deserves clarification: what characterizes it? who uses it in which situations? how should this influence our teaching? and so forth. This issue also raised the importance of locally produced - or at least relevant - materials, as well as addressing the environment outside the classroom in ESL/EFL contexts. In her study of adult ESL in Ireland, D. Murphy (2011) found that while pronunciation was regarded as a valuable element of English language learning, little innovation in teaching practice was observed. Particularly 
problematic was the discrepancy between the model of English pronunciation being used by teachers, and the model on which materials were based. Arguably in some teaching contexts there is a parallel mismatch between materials and context when non-native English speakers, who might feel most comfortable teaching RP, are faced with a set of youngsters who, obsessed with American games or TV series, have adopted American accent features.

The survey presented in this paper is a pilot study, and as such, will be improved and expanded on in further work. Certain items will need reworking, and certain themes will need developing. Participation levels were sometimes uneven across the countries, leading to the abandoning of data from Ireland, The Netherlands and Sweden. In discussions it has become clear that in some contexts a paper-based survey might have been more successful. Distribution was uneven within countries, with certain areas being over-represented, e.g. the Francophone areas of Switzerland dominate the Swiss results, and in France there are few participants from secondary schools or the private sector. This means that sometimes it has not been possible to make certain cross-country comparisons as we would not be comparing like with like.

The perspectives for further research are vast. Most importantly, the rest of the data (e.g. concerning teaching conditions, methodology, technology, etc.) will be analysed and follow-up phone interviews will be carried out. It would also be useful to compare the data with learner surveys, shedding light on some of the more ambiguous findings. Above all, we would like to use the experience we have gained from this collaborative project by continuing to explore how varieties of English are chosen, taught and perceived across Europe.

\section{Acknowledgements}

We would like to express heartfelt thanks to all of the teachers who took the time to participate in this survey, including those in countries which were not covered by this article.

\section{References}

Donovan, P.J. 2001. Making Pronunciation a Priority for EFL Teachers and Learners. In Levey, D., Losey, M.A. \& González, M.A. (Eds.). English Language Teaching Changing Perspectives in Context. Cádiz: Universidad de Cádiz (Servicio de Publicaciones). 245-249.

Duchet, J-L. 1991. Code de l'anglais oral. Paris: Ophrys.

Dürmüller, U. 2002. English in Switzerland: From Foreign Languages to Lingua Franca. In D.Allerton, P.Skandera, C.Tschichold (Eds), Perspectives on English as a World Language, Basel: Schwabe. 114-123.

Foote, J.A., Holtby, A.K. \& Derwing, T.M. 2011. Survey of the Teaching of Pronunciation in Adult ESL Programs in Canada, 2010. TESL Canada Journal 29(1), $1-22$. 
Frost, D. 2010. Stress cues in English and French: a perceptual study. Journal of the International Phonetic Association, 41(01): 67-84.

Gonet, W., Szpyra-Kozłowska, J. \& Święciński, R. 2010. Clashes with ashes - The acquisition of vowel reduction by Polish students of English. In Waniek Klimczak, E. (Ed.) Issues in Accents of English 2. pp. 213-232. Newcastle upon Tyne: Cambridge Scholars Publishing.

Hilgendorf, Suzanne K. 2007. English in Germany: Contact, Spread, and Attitudes. World Englishes. 26.2: 131-148.

Hirst, D. \& A. Di Cristo (Eds.). 1998. Intonation Systems: A Survey of Twenty Languages. Cambridge: Cambridge University Press.

Janicka, K., M. Kul, \& J. Weckwerth. 2005. Polish students' attitudes to native English accents. In Dziubalska-Kołaczyk, K. \&. Przedlacka, J. (Eds.) English pronunciation Models: A changing scene. Bern: Peter Lang. pp. 251-292.

Kangasvieri, T., E. Miettinen, P. Kukkohovi \& M. Härmälä. 2011. Kielten tarjonta ja kielivalintojen perusteet perusopetuksessa. Muistiot 2011:3. Helsinki: Finnish National Board of Education.

Kopperoinen, A. 2011. Accents of English as a lingua franca: a study of Finnish textbooks. International Journal of Applied Linguistics 21(1), 71-93.

Levey, D. 2001. Stressing Intonation. In Harris, T., Roldan, I., Sanz, I, \&. Torreblanco, M. (Eds.) ELT2000: Thinking Back, Looking Forward. Granada: Greta. 35-45.

Levey, D. 1999. Half Truths and White Lies: A Practical Pronunciation Guide for Spanish Speakers. In Harris, T. \& Sanz, I. (Eds.) ELT: Through the Looking Glass. Granada: Greta. 215-226.

Lintunen, P. 2004. Pronunciation and Phonemic Transcription: A study of advanced Finnish learners of English. Turku: University of Turku.

Murphy, D. 2011. An investigation of English pronunciation teaching in Ireland. English Today, 27(4), 10-18.

Murphy, J.M. 1997. Phonology courses offered by MA TESOL programs in the US. TESOL Quarterly 31, 741-761.

Paunović, T. 2009. Plus ça change... Serbian EFL students' attitudes towards varieties of English. Poznań Studies in Contemporary Linguistics, 45(4), 511-533. Retrieved from http://versita.metapress.com/content/6563h54842u858nm/fulltext.pdf

Pavon, V. 2001. El Papel del Profesor en la Enseñanza de la Pronunciación. In Levey, D., Losey, M.A. \& González, M.A. (Eds.). English Language Teaching Changing Perspectives in Context. Cádiz: Universidad de Cádiz (Servicio de Publicaciones). 289-300.

Pavon, V. \& Rosado, A. 2003. Guía de Fonética y Fonología para Estudiantes de Filología Inglesa en el Umbral del Siglo XXI. Granada: Comares

Sajavaara, K., Luukka, M-R. \& Pöyhönen, S. 2007. Kielikoulutuspolitiikka Suomessa: Lähtökohtia, ongelmia ja tulevaisuuden haasteita. In Pöyhönen, S. \& Luukka, M-R. (Eds.), Kohti tulevaisuuden kielikoulutusta. Kielikoulutuspoliittisen projektin loppuraportti. University of Jyväskylä: Centre for Applied Language Studies.

Sockett, G. 2011. From the cultural hegemony of English to online informal learning: Cluster frequency as an indicator of relevance in authentic documents, Asp, la revue du GERAS, 60, 5-20. 
Statistisches Bundesamt (www.desatis.de). 2003a. Bildung und Kultur. Allgemeinbildende Schulen [Education and Culture. Schools of general Education]. Fachserie 11, Reihe1. Wiesbaden.

[http://www.destatis.de/jetspeed/portal/cms/Sites/destatis/Internet/DE/Content/Publik ationen/Fachveroeffentlichungen/BildungForschungKultur/Schulen/Allgemeinbilden deSchulen2110100037004,property=file.pdf; retrieved 2012-02-13]

Statistisches Bundesamt (www.desatis.de). 2011a. Bildung und Kultur. Allgemeinbildende Schulen [Education and Culture. Schools of general Education]. Fachserie 11, Reihe1. Wiesbaden.

[http://www.destatis.de/jetspeed/portal/cms/Sites/destatis/Internet/DE/Content/Publik ationen/Fachveroeffentlichungen/BildungForschungKultur/Schulen/Allgemeinbilden deSchulen2110100117004,property=file.pdf; retrieved 2012-02-13]

Statistisches Bundesamt (www.desatis.de). 2003b. Bildung und Kultur. Berufliche Schulen [Education and Culture. Vocational schools]. Fachserie 11, Reihe1. Wiesbaden.

[http://www.destatis.de/jetspeed/portal/cms/Sites/destatis/Internet/DE/Content/Publik ationen/Fachveroeffentlichungen/BildungForschungKultur/Schulen/BeruflicheSchule n2110200047004,property=file.pdf; retrieved 2012-02-13]

Statistisches Bundesamt (www.desatis.de). 2011b. Bildung und Kultur. Berufliche Schulen [Education and Culture. Vocational schools]. Fachserie 11, Reihe1. Wiesbaden.

[http://www.destatis.de/jetspeed/portal/cms/Sites/destatis/Internet/DE/Content/Publik ationen/Fachveroeffentlichungen/BildungForschungKultur/Schulen/BeruflicheSchule n2110200117004,property=file.pdf; retrieved 2012-02-13]

Taillefer, G. 2002. L'anglais dans les formations spécialisées à l'Université :un cheveu sur la soupe? Peut-on rendre le plat plus appétissant ?, ASP 37-38, 155-172.

Tergujeff, E. 2009. Accent addition in Finnish EFL textbooks. Presentation given at the 3rd International conference on native and non-native accents of English, 12.12.2009 Lodz, Poland.

Tergujeff, E. 2010a. Pronunciation teaching materials in Finnish EFL textbooks. In Henderson, A. (Ed.), English Pronunciation: Issues and Practices (EPIP): Proceedings of the First International Conference. June 3-5 2009, Université de Savoie, Chambéry, France. Université de Savoie: Laboratoire LLS.

Tergujeff, E. 2010b. Model pronunciation in Finnish EFL textbooks. Presentation given at NAES-FINSSE 2010: English in the North, 11.6.2010 Oulu, Finland.

Tergujeff, E. (in print). English pronunciation teaching: Four case studies from Finland. Journal of Language Teaching and Research, 43.

Tergujeff, E., Ullakonoja, R. \& Dufva, H. (2011). Phonetics and Foreign Language Teaching in Finland. In Werner, S. \& Kinnunen, T. (eds.), XXVI Fonetiikan päivät 2010. Joensuu, Finland: University of Eastern Finland. 63-68.

Nowacka, M. 2010. The ultimate attainment of English pronuncitaion by Polish college students: A longitudinal study. In Waniek-Klimczak, E. (Ed.) Issues in Accents of English 2.Newcastle upon Tyne: Cambridge Scholars Publishing. 233-260. 
Vaissière, J. 2002. Cross-Linguistic Prosodic Transcription: French versus English. Problems and Methods in Experimental Phonetics, In honour of the 70th anniversary of Prof. L.V. Bondarko,. N. B. Volslkaya, N. D. Svetozarova and P. A. Skrelin. St.Petersburg. 147-164.

Waniek-Klimczak, E. \& K. Klimczak. 2005. Target in speech development: learners' views. In K. Dziubalska-Kołaczyk \&. J. Przedlacka (Eds.) English pronunciation Models: A changing scene. Bern: Peter Lang. 229-250. 